\title{
Geochemistry of post-tectonic mafic intrusions in the Central Gneiss Terrane of southwestern Newfoundland
}

\author{
K.L. Currie and J.T. van Berkel* \\ Geological Survey of Canada, 601 Booth Street, Ottawa, Ontario K1A OE8, Canada
}

Date Received January 17, 1989

Date Accepted September 18, 1989

\begin{abstract}
South of Grand Lake, mafic igneous complexes of proven or probable Silurian age intruded quartzofeldspathic gneisses that had been deformed and raised to granulite facies in mid-Ordovician time. The mafic igneous complexes consist of gabbroic units, which locally exhibit igneous layering and contain ultramafic cumulate pods, that grade to and are cut by finer-grained homblende gabbro. Compositions more felsic than diorite exhibit intrusive to co-mingling relationships with more mafic rocks. Chemical data for possible liquid-derived rocks exhibit characteristics suggesting derivation from diverse mantle sources, followed by varying combinations of fractionation, contamination, mixing and metasomatism by hydrous fluids during ascent and emplacement. The post-tectonic emplacement of the plutons suggests stabilisation of the Central Gneiss Terrane by late Ordovician or Silurian time, when the adjacent terrane to the southeast (Meelpaeg Terrane) was still undergoing deformation and granitic plutonism.
\end{abstract}

\begin{abstract}
Au sud de Grand Lake, des complexes ignés mafiques, dont l'âge est assurément ou probablement silurien, firent intrusion dans des gneiss quartzofeldspathiques qui avaient été déformés et avaient atteint le faciès des granulites au milieu de l'Ordovicien. Les complexes ignés mafiques sont constitués d'unités gabbrö̈ques (montrant localement un aspect rubanné et contenant des lentilles de cumulats ultramafiques) passant graduellement à un gabbro à homblende moins grenu qui les recoupe aussi. Les compositions plus felsiques que la diorite sont en relation d'intrusion ou de mélange avec les roches plus mafiques. Les données chimiques concernant des roches possiblement dérivées du liquide montrent des caractères suggérant une dérivation à partir de diverses sources mantelliques, suivie d'une combinaison variée de fractionnement, contamination, mélange et métasomatisme par des fluides aqueux durant l'ascension et l'emplacement. L'emplacement post-tectonique des plutons suggère une stabilisation de la lanière Central Gneiss Terrane avant l'Ordovicien tardif ou le Silurien, au moment où la lanière adjacente au sud-est (la Lanière de Meelpaeg) subissait encore une déformation et un plutonisme granitique.
\end{abstract}

[Traduit par le joumal]

\section{INTRODUCTION}

The Central Gneiss Terrane (van Berkel et al., 1986) of the southern Long Range of Newfoundland consists mainly of highgrade gneisses and foliated granitoid rocks, with rare elongate shreds of ophiolitic rocks and scattered, little deformed mafic bodies (Fig. 1). The gneisses and granitoid rocks gave middle Ordovician radiometric ages (Stevens et al., 1982; Dunning and Chorlton, 1985). Dunning et al. (1988) reported an age of $431 \pm 2$ $\mathrm{Ma}$ (U-Pb on zircon) for the Main Gut mafic complex. The age of the other mafic complexes is not definitely known, but on the basis of similar undeformed character, similar to identical petrography, and lack of known igneous rocks younger than Silurian in this part of Newfoundland (Whalen et al., 1987), they are assumed to be of similar late Ordovician to Silurian age. In sharp contrast to the undeformed Ordovician to Silurian mafic rocks, voluminous Silurian deformed granitoid rocks outcrop only a few kilometres to the southeast across the Victoria River fault (Dunning et al., 1988). An understanding of the tectonic setting of the mafic bodies would help to understand this major tectonic boundary and to elucidate the complex tectonic history of southwestem Newfoundland.

\section{GEOLOGICAL SETTING}

The part of western Newfoundland discussed in this paper can be divided into six geological segments separated by major faults marked by mylonite or breccia zones hundreds or thousands of meters wide (Fig. 1). The terminology and kinematic development of this region have recently been discussed by Williams et al. (1988) and Currie and Piasecki (in press). Platformal rocks of Cambrian-Ordovician age, locally veneered by easterly derived allochthons, outcrop west of the Grand Lake fault (Williams and Cawood, 1985). Between the Grand Lake and Long Range faults, high-grade Proterozoic metamorphic rocks, upper Precambrian meta-scdimentary rocks and late Precambrian granitic plutons of peralkaline affinities (Currie, 1987; van Berkel and Currie, 1988) occur in westerly transported thrust slices.

*Present address: Institute of Earth Sciences, Free University, P.O. Box

7161, 1007 MC Amsterdam, The Netherlands

Geological Survey of Canada Contribution Number 32288.

ATLANTIC GEOLOGY

$25,181-190$ (1989) 


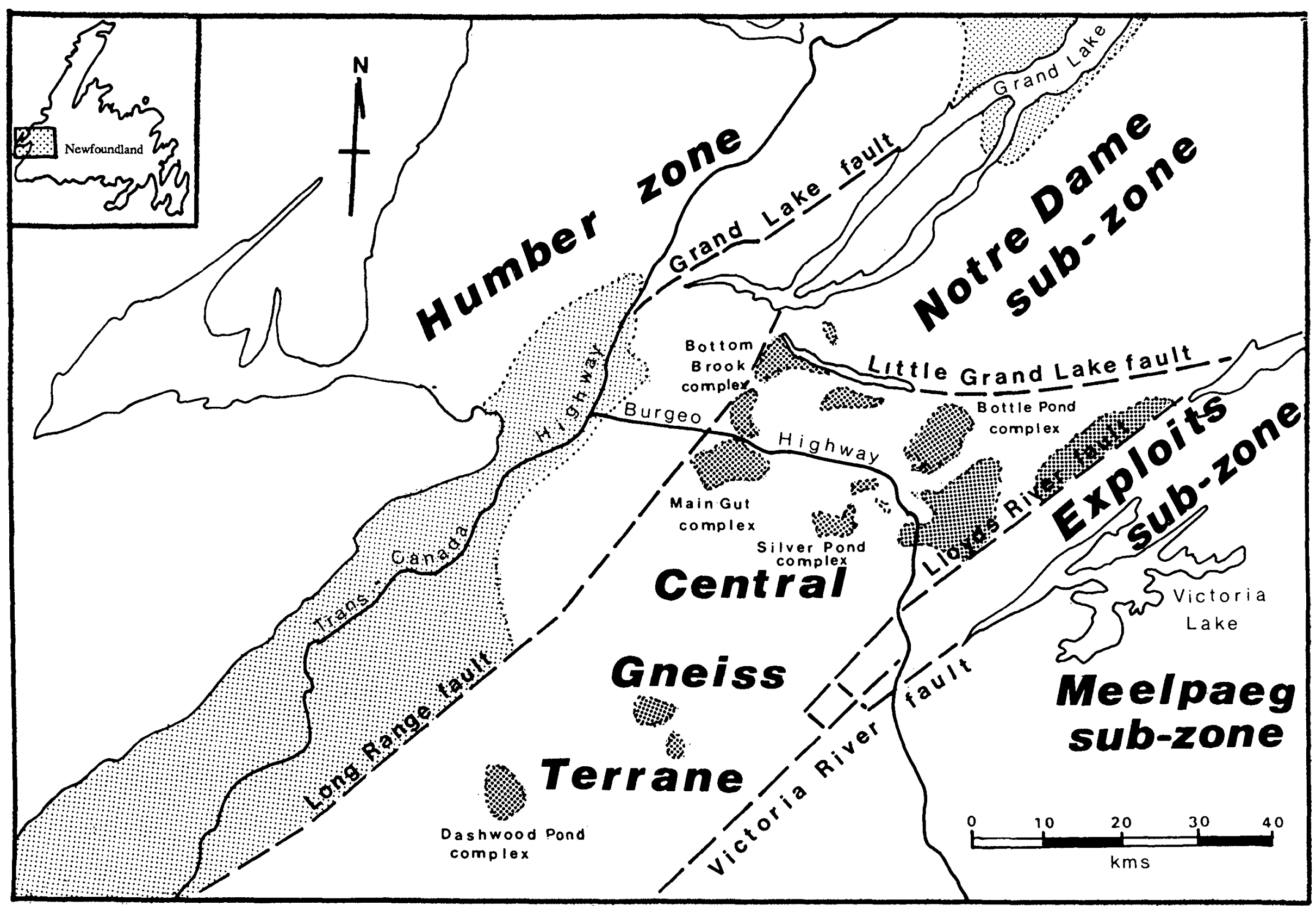

Fig. 1. Geological terranes and major faults in southwestern Newfoundland. The terminology follows that of Williams et al. (1988) and Currie and Piasecki (1988). Dashed lines - major faults, mafic bodies - dark stipple, Carboniferous sedimentary basins - light stipple. 
The area between the Long Range, Little Grand Lake and Lloyds River faults (Central Gneiss Terrane) consists of highgrade quartzofeldspathic gneisses, including minor semi-pelitic and calcareous rocks, invaded by variably foliated granitoid intrusions and massive mafic bodies. Ultramafic rocks of ophiolitic affinities occur in narrow ( $<500 \mathrm{~m}$ ) sinuous strips bounded by high strain zones (Fox and van Berkel, 1988). Middle Ordovician radiometric ages have been obtained from both gneisses and granitoid intrusions (Stevens et al., 1982; Dunning and Chorlton, 1985). North of the Little Grand Lake fault, undeformed early Silurian A-type granites intruded plutons of Ordovician age (Whalen et al., 1987) and little metamorphosed Ordovician volcano-sedimentary suites of ophiolitic affinity. This region has been thrust southward along the Little Grand Lake fault (Whalen and Currie, 1983; van Berkel and Currie, 1988; Currie and Piasecki, in press).

Two quite different geological sequences lie southeast of the Central Gneiss Terrane (Fig. 1). In the north, the ophiolitic, early Ordovician Annieopsquotch complex (Dunning, 1987), mafic and felsic volcanic rocks of the middle Ordovician Victoria Lake Group (Dunning et al., 1988), and Silurian volcano-sedimentary rocks (Chandler and Dunning, 1983) occur southeast of a fault following the Lloyds River valley. Farther south, across the Victoria River fault, migmatitic metasedimentary rocks of uncertain age, characterised by calc-silicate lentils, contain late to postkinematic S-type granites.

The history and kinematics of motions which assembled these diverse lithologies are not completely understood, but Silurian sinistral motions succeeding middle Ordovician ocean closure seem required by the field observations (Currie and Piasecki, in press).

\section{GEOLOGY OF THE MAFIC INTRUSIONS}

We have mapped and sampled eight mafic complexes within the Central Gneiss Terrane (Fig. 1). These complexes form equant to lobate masses, fresh except for minor chlorite-epidote alteration and uralitization of pyroxene. The complexes all locally exhibit igneous phenomena such as ophitic texture, zoned plagioclase and phase layering, in marked contrast to their granoblastic to blastomylonitic host rocks. Several complexes are cut by late, brittle faults, but none of them shows any penetrative foliation and there is no apparent systematic relationship between faults and mafic complexes. No unfaulted contacts with host rocks have been observed, but the presence of numerous enclaves of surrounding gneisses in the Dashwood Pond and Bottle Pond bodies shows that they intruded their host, and other bodies appear to exhibit chilled marginal units.

The complexes consist of various mixtures of medium- to coarse-grained units with cumulate texture and finer-grained units with ophitic texture. Coarse-grained rocks consist of labradoritic plagioclase laths, orthopyroxene (commonly partially rimmed or replaced by hornblende), clinopyroxene and varying amounts of opaques. Patches of massive, coarse to pegmatitic material are abundant. Locally igneous layering, ranging from crude and patchy to very regular, is defined by plagioclase and pyroxene enrichment, or in the Main Gut com- plex by magnetite seams. Segregations of pyroxenite up to 100 $\mathrm{m}$ long, presumably of cumulate origin, contain olivine which is not found in more feldspathic rocks.

Fine-grained ophitic units occur on the margins of all the complexes, possibly representing chilled margins which may be up to $20 \mathrm{~m}$ thick, and also as intemal irregular, diffuse bodies up to $10 \mathrm{~m}$ wide which tend to trend northeast. Fine-grained rocks commonly show completely gradational boundaries with the coarser phases, but some internal bodies locally cut and include the coarse units. Fine-grained rocks consist of roughly equal amounts of andesine and hornblende in ophitic to sub-ophitic texture. In the Dashwood Pond and Silver Pond bodies the finegrained rocks are distinctly more leucocratic than their host (colour index of 30-40 compared to $>50$ ).

Felsic rocks form a negligible part of these complexes. In the Bottle Pond complex, narrow $(<50 \mathrm{~cm})$ monzonitic to syenitic dykes exhibit complex cuspate margins and fine-grained mafic globules suggestive of comingling of felsic and mafic magmas. Rare dykes of tonalitic to granodioritic composition cut the Main Gut complex and may represent felsic phases of this complex.

\section{GEOCHEMISTRY}

In Table 1 we present 25 new analyses of mafic rocks from five bodies, as well as 6 analyses of the Main Gut complex from Carew (1979). Two analyses are of ultramafic rocks, (analyses 1 and 16), two of coarse-grained gabbro (analyscs 2 and 8 ) and the rest of fine- to medium-grained homogeneous rocks. The new analyses were made by X-Ray Assay Laboratories, Toronto. Major element analyses were made by $\mathrm{X}$-ray fluorescence, with a separate colorimetric determination of $\mathrm{Fc}_{2} \mathrm{O}_{3}$, and trace element analyses by a combination of $\mathrm{X}$-ray fluorescence and instrumental neutron activation. The stated precision of major element analyses relative to instrument stability and sample preparation range from standard deviations of $0.32 \mathrm{wt} . \%$ for $\mathrm{SiO}_{2}$ down to 0.005 for $\mathrm{TiO}_{2}$. Similar figures for trace elements range from 10 to $20 \%$ of amount present. Results on blind duplicates included in the sample batch suggest that this precision was maintained.

Petrographic features such as laycring and ultramafic lenses suggest that most of the coarse-grained rocks in the complexes are of cumulate origin. The finer-grained rocks could be derived from liquid, although the very low content of $\mathrm{Zr}$ and $\mathrm{Y}$ in finegrained ophitic rocks of the Dashwood Pond and Silver Pond samples suggests these bodies may consist mainly of cumulate material. If an element is not significantly cxtracted during fractionation, then ratio plots using this clement as a denominator can be used to investigate sources of variation in the analyses (Pearce, 1968; Russell, 1986). Nonc of the analysed samples contains a primary K-rich phasc. We thereforc assume $\mathrm{K}$ to be a suitable denominator element. A plot of $\mathrm{Fc} / \mathrm{K} v \mathrm{Mg} / \mathrm{K}$ (Fig. 2a) gives straight lines for each complex suggestive of extraction of a mafic phase with mg number ncar 70 for Main Gut and Botle Pond, and slightly over 80 for the other complexcs. The ultramafic samples plot far off the diagram to the upper right. A plot of $\mathrm{Al} / \mathrm{K}$ against $\mathrm{Ca} / \mathrm{K}$ (Fig. 2b) shows a lincar rclation for all samples suggesting plagioclase and pyroxenc extraction. For Dashwood Pond and Silver Pond, Na/K plotted against $\mathrm{Ca} / \mathrm{K}$ 


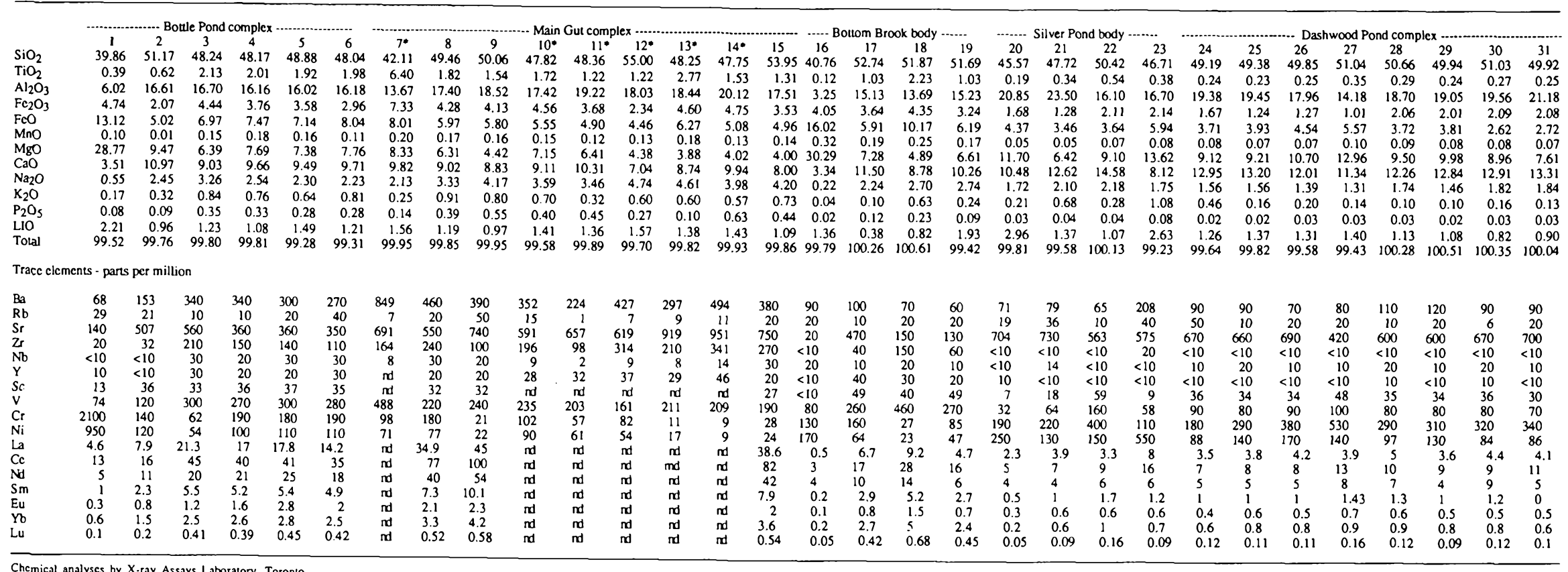



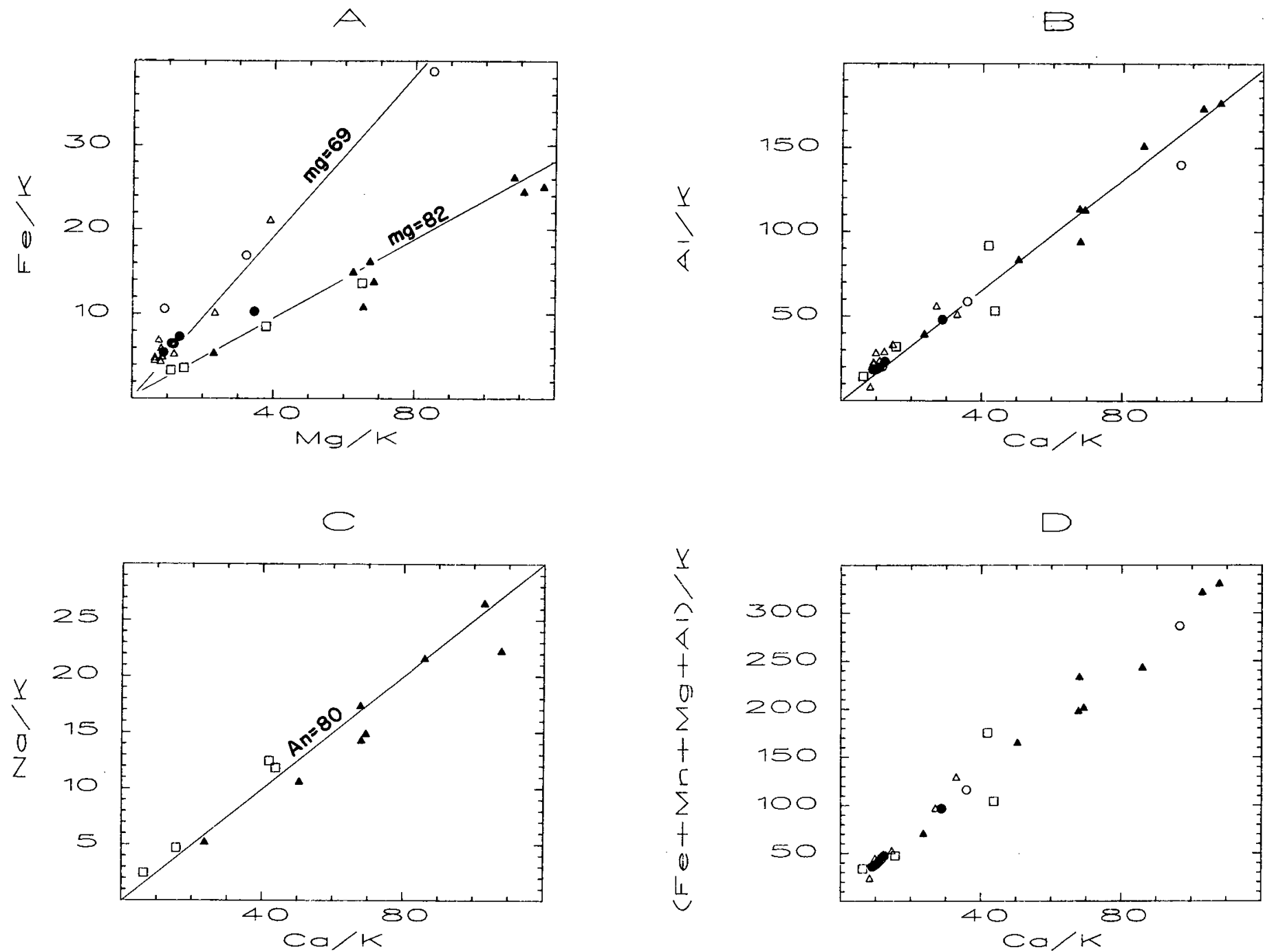

Fig. 2. Element ratio plots for mafic intrusions of the Central Gneiss Terrane, Bottle Pond - solid circles, Main Gut - open triangles, Bottom Brook - open circles, Silver Pond - open squares, Dashwood Pond - closed triangles. (A) Plot of $\mathrm{Fe}$ (total)/K against $\mathrm{Mg} / \mathrm{K}$. The lines show the result of extraction of mafic phases with mg numbers of 69 and 82 , respectively. Ultramafic samples have $\mathrm{Fe} / \mathrm{K}$ and $\mathrm{Mg} / \mathrm{K}>200$ and do not plot near the extension of either line. (B) Plot of $\mathrm{Al} / \mathrm{K}$ against $\mathrm{Ca} / \mathrm{K}$. The line shows the result of extraction of $75 \%$ An 80 and $25 \%$ diopside (assumed to lack $\mathrm{Al}$ ). Note that the data points cannot be modelled by extraction of plagioclase alone because $\mathrm{Al} / \mathrm{Ca}<2$. (C) $\mathrm{Plot}$ of $\mathrm{Na} / \mathrm{K}$ against $\mathrm{Ca} / \mathrm{K}$ for samples from the Dashwood Pond and Silver Pond complexes. Solid line shows the result of extraction of plagioclase of composition An 80 . Other complexes also exhibit linear plots, but with differing slopes. (D) Plot of $(\mathrm{Al}+\mathrm{Fe}+\mathrm{Mn}+\mathrm{Mg}) / \mathrm{K}$ against $\mathrm{Ca} / \mathrm{K}$. Ultramafic samples have $(\mathrm{Al}+\mathrm{Fe}+\mathrm{Mn}+\mathrm{Mg}) / \mathrm{K}>500$ and plot above the linear trend.

gives a linear relation with $\mathrm{Ca} / \mathrm{Na}$ about 4 (Fig. 2c), compatible with extraction of plagioclase of composition An 80. $(\mathrm{Al}+\mathrm{Fe}+\mathrm{Mn}+\mathrm{Mg}) / \mathrm{K}$ against $\mathrm{Ca} / \mathrm{K}$ (Fig. 2d) gives a well-defined linear trend, except for the two ultramafic samples. These plots suggest that all specimens except the two ultramafics could result by extraction of orthopyroxene (and/or olivine), plagioclase and varying amounts of clinopyroxene from a liquid, and that the use of discrimination diagrams designed for basaltic liquids should give meaningful results. As Dashwood Pond and Silver Pond show trends similar to those of the other complexes, the low $\mathrm{Zr}$ and $Y$ contents may be a primary feature.

Figures 3 and 4 show the position of analyses of fine-grained homogeneous rocks on some discrimination diagrams for basaltic liquids. On a standard A-F-M ( $\mathrm{Na}_{2} \mathrm{O}+\mathrm{K}_{2} \mathrm{O}-\mathrm{FeO}$ (total)- $\left.\mathrm{MgO}\right)$ plot (Fig. 3a) Dashwood Pond and Silver Pond samples lie well within the calc-alkaline field, whereas other complexes plot mainly in transitional or tholeiitic fields. On the $\mathrm{MgO}-\mathrm{FeO}_{\text {- }}$ $\mathrm{Al}_{2} \mathrm{O}_{3}$ plot (Fig. 3b) analyses spread over a considerable area of the orogenic and ocean floor fields, with the Bottom Brook samples plotting in or near the continental field. On a $\mathrm{TiO}_{2}-\mathrm{K}_{2} \mathrm{O}$ $\mathrm{P}_{2} \mathrm{O}_{5}$ plot (Fig. 3c) most analyses plot in the non-oceanic field, but a few from Dashwood Pond and Bottom Brook lie in the oceanic field. The Ti-Zr-Y classification of Pearce and Cann (1973) must be attempted with caution because the $\mathrm{Zr}$ values for some samples are too low to be analytically reliable $(<10 \mathrm{ppm})$. We have therefore plotted only samples with $\mathrm{Zr}>20 \mathrm{ppm}$ and $\mathrm{Y}>10$ ppm (Fig. 3d). Eight of 14 samples plot in, or on the edge of, the within-plate basalt field, and four plot in arc-type basalt fields. None of the samples from Dashwood Pond or Silver Pond are included on this plot because of their low $\mathrm{Zr}$ and $\mathrm{Y}$ values. The 

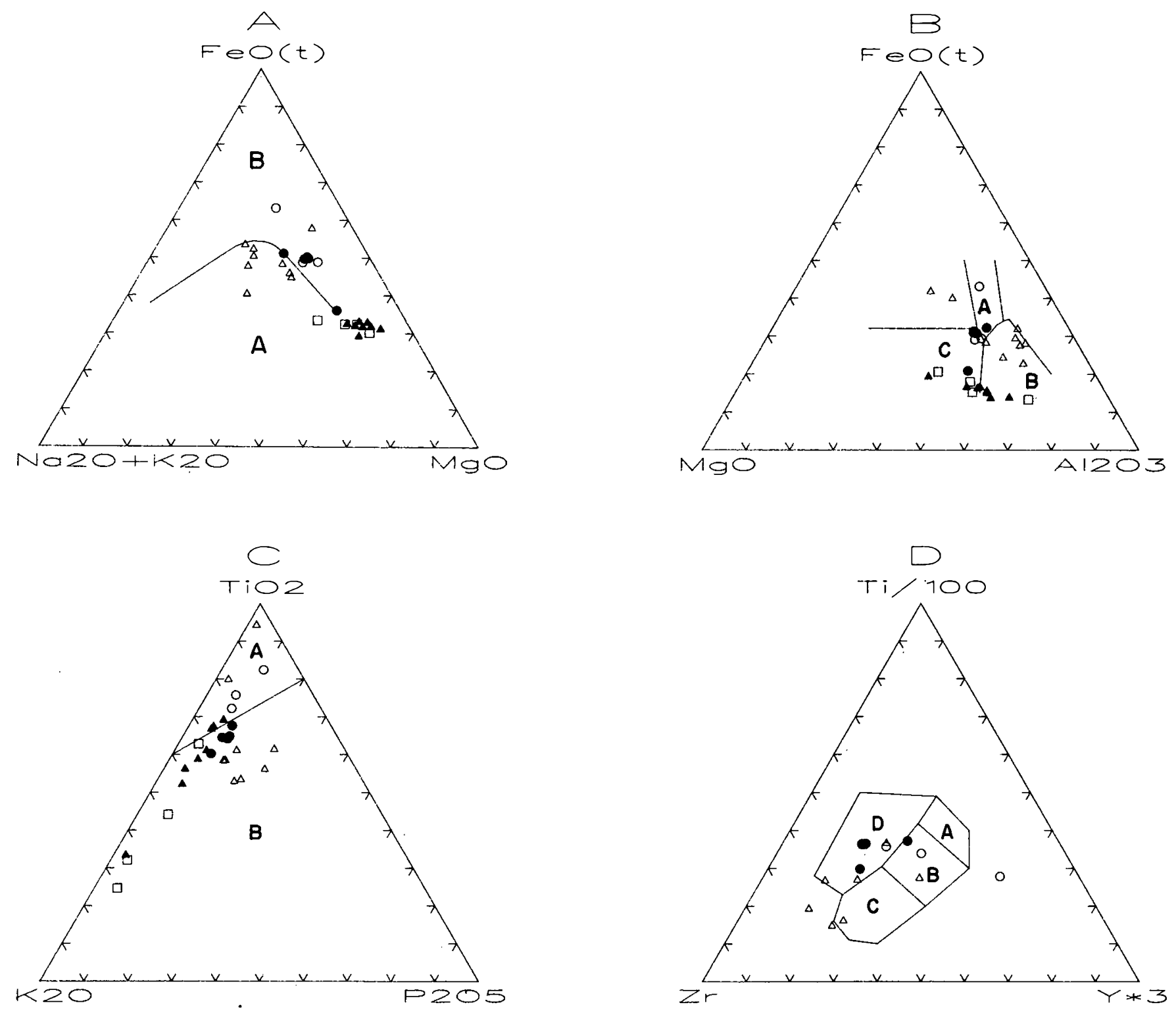

Fig. 3. Temary geochemical plots for mafic plutons of the Central Gneiss Terrane (symbols as in Fig. 2). (A) A-F-M plot ( $\mathrm{Na}_{2} \mathrm{O}+\mathrm{K}_{2} \mathrm{O}-\mathrm{FeO}$ (total)$\mathrm{MgO}$ ) (after Irvine and Baragar, 1971). A - calc-alkaline suites, B - tholeiitic suites. (B) $\mathrm{MgO}-\mathrm{FeO}$ (total)- $\mathrm{Al}_{2} \mathrm{O}_{3}$ plot (after Pearce et al., 1977). A - continental suites, B - orogenic suites, C - MORB. (C) $\mathrm{TiO}_{2}-\mathrm{K}_{2} \mathrm{O}-\mathrm{P}_{2} \mathrm{O}_{5}$ plot (after Pearce et al., 1975). A - oceanic suites, B - continental suites. (D) Ti/100-Zr-3*Y (after Pearce and Cann, 1973). A,B - island arc tholeiites (low K tholeiites), B - ocean floor basalts, B,C - calc-alkaline basalts, $\mathrm{D}$ - continental basalts. Only analyses with $>20 \mathrm{ppm} \mathrm{Zr}$ and $>10 \mathrm{ppm}$ Y plotted.

total Fe - total Fe/MgO plot of Miyashiro and Shido (1975) shows the analyses to scatter from the tholeiitic field across the transitional field into the calc-alkaline field, but mainly to lie near the mid-ocean ridge basalts (MORB) field (Fig. 4a). On the Ti-V plot of Shervais (1982), the data form a roughly linear array with Ti/ $V$ between 20 and 50. Dashwood Pond and Silver Pond samples plot in arc-related fields, whereas other complexes plot mainly in the MORB field (Fig. 4b). On the Ti-Cr plot of Pearce (1975) most analyses fall in the arc-related field, but Bottle Pond analyses do not (Fig. 4c). Main Gut samples plot in within-plate field on the $\mathrm{TiO}_{2}-\mathrm{Zr}$ plot of Pearce (1982), whereas Bottom Brook and Bottle Pond samples straddle both fields (Fig. 4d). Only one of the Dashwood Pond and Silver Pond samples has been plotted due to low $\mathrm{Zr}$ content.
Rare earth element data (Table 1) show little within-pluton variation, but marked between-pluton variations. Representative analyses for Bottle Pond and Main Gut (Fig. 5a) exhibit La enrichment up to $100^{*}$ chondritic values, $\mathrm{La} / \mathrm{Yb}$ ratios up to 11 , and lack significant europium anomalies. These characteristics suggest derivation from an enriched source. The other three bodies exhibit $\mathrm{La}$ enrichment less than 25 times chondritic, La/ $\mathrm{Yb}$ ratios less than 7 , and also lack significant europium anomalies. They could be derived from a normal, or even depleted source. Representative spidergrams of trace element abundances normalized against MORB values of Pearce et al. (1981) show similar divisions (Fig. 5b, c). Bottle Pond and Main Gut exhibit enrichments in feldspar-related related elements $(\mathrm{Sr}, \mathrm{K}, \mathrm{Rb}, \mathrm{Ba}$ ) of as much as 20 times MORB, with higher charge density 

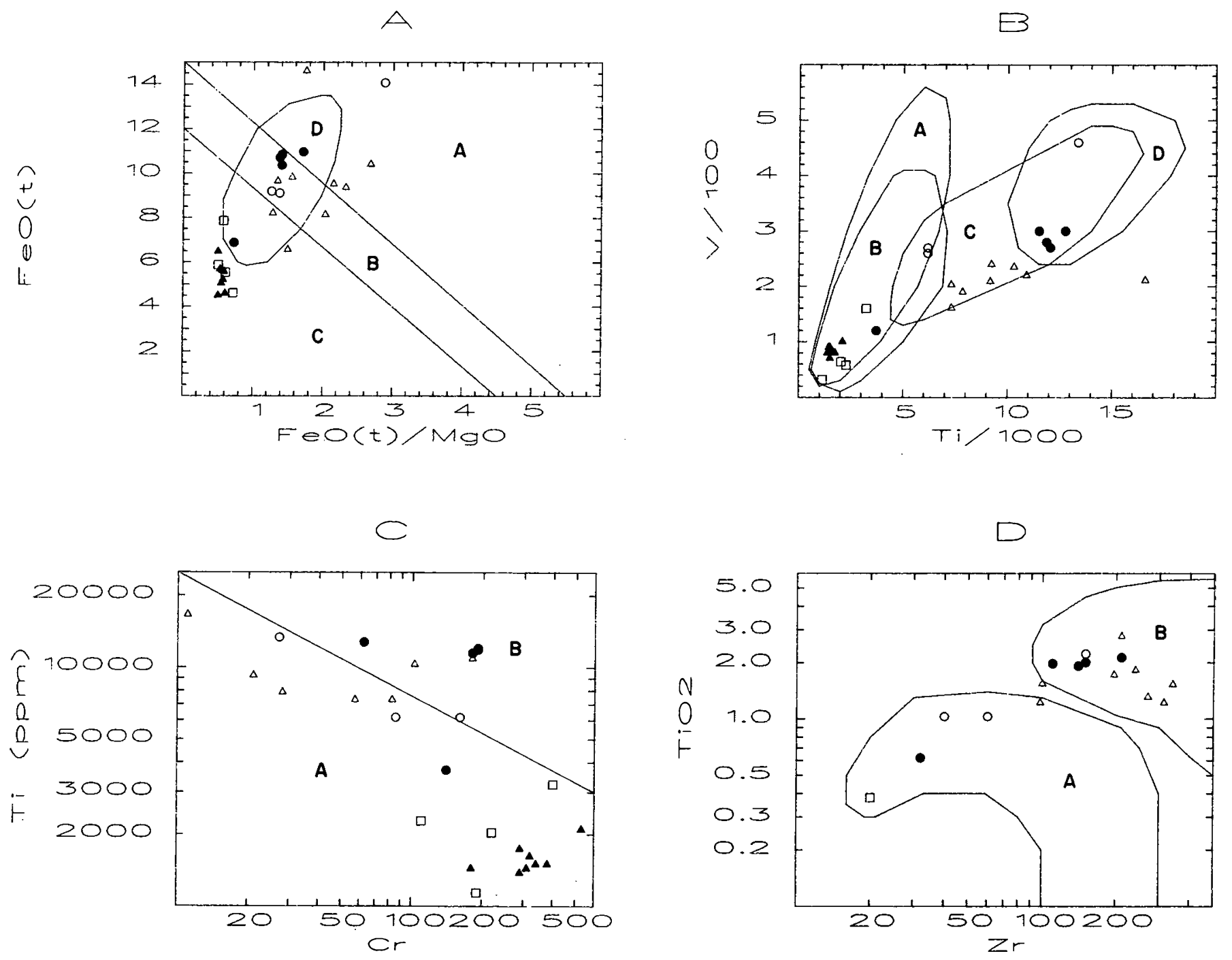

Fig. 4. Binary geochemical plots for mafic plutons of the Central Gneiss Terrane (symbols as in Fig. 2). (A) Total FeO-total FeO/MgO plot (Miyashiro and Shido, 1975). A - tholeiitic basalts, B - transitional basalts, C - calc-alkaline basalts, D - MORB. (B) Ti-V plot (after Shervais, 1982). A - arc tholeiites, B - calc-alkaline basalts, C - MORB, D - plateau basalts. (C) Ti-Cr plot (after Pearce, 1975). A - Arc-related basalts, B - compositions outside the field of arc-related basalts. (D) Zr-TiO2 plot (after Pearce, 1982). A - arc related suites, B - within-plate suites.

elements declining smoothly to MORB values. Such patterns resemble within-plate tholeiites (Fig. 5b). Dashwood Pond and Silver Pond exhibit lower enrichment in feldspar-related elements and striking depletion of high charge density elements to less than 0.4 MORB values. Such patterns resemble volcanic arc tholeiites (Fig. 5c). Bottom Brook samples plot between the two extremes.

\section{DISCUSSION}

All of the bodies discussed in this contribution are posttectonic and none consistently show MORB-like characteristics. Hence they cannot be correlated either with Ordovician ophiolitic complexes such as the nearby Annieopsquotch complex (Dunning, 1987), or with Silurian MORB-type complexes in Gaspé thought to be related to wrench faults (Bedard, 1987). However probably correlative mafic magmatism of early Silurian age occurred in terranes contiguous to the Central Gneiss
Terrane. Whalen et al. (1987) noted that the Rainy Lake complex of the Notre Dame sub-zone ( $438 \pm 8 \mathrm{Ma}$ ) exhibits arc-like character, even though associated with a continental igneous suite (Topsails igneous suite). Dunning (1987) found that posttectonic mafic plutons of similar age $(435+5 /-2 \mathrm{Ma})$ and petrography cut the Annieopsquotch complex east of the Lloyds River fault. We suggest that this mafic plutonism defines a distinctive igneous suite, demonstrating that the region northwest of the Victoria River fault had been assembled by early Silurian time, and that pervasive penetrative deformation and accompanying metamorphism were essentially absent. In contrast, Dunning $e t$ al. (1988) showed that to the southeast of the Victoria River fault, metamorphism, deformation and orogenic plutonism were in progress as late as $420 \mathrm{Ma}$. The Victoria River fault therefore represents a major tectonic boundary separating regions with different Silurian histories. Northwest of this boundary, the presence of middle Ordovician granulite-facies metamorphism and little deformed lower Silurian volcanic and sedimentary 


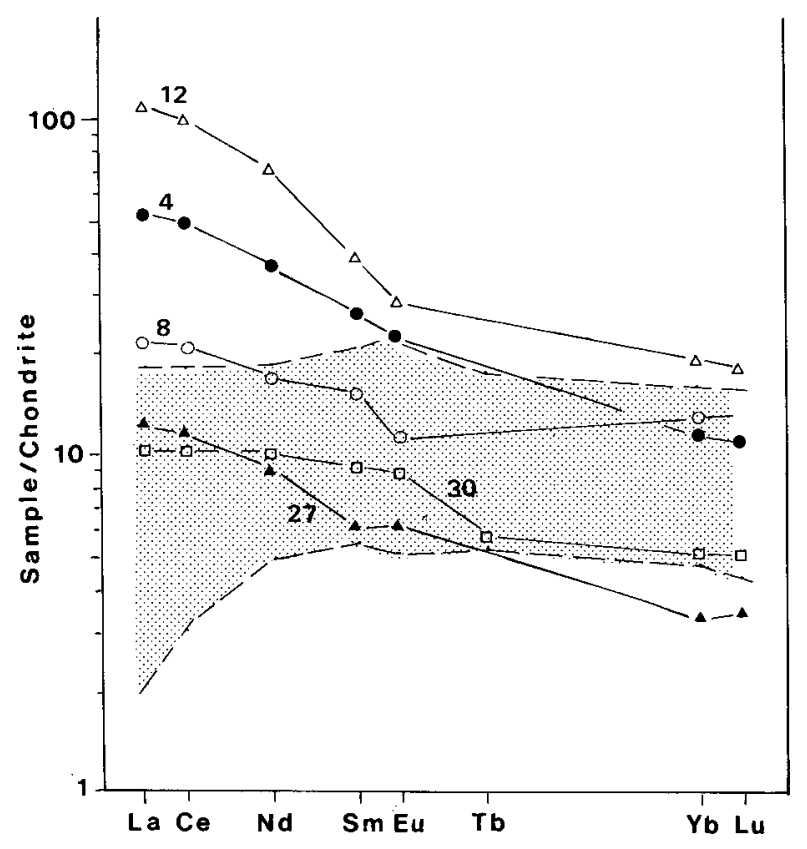

A

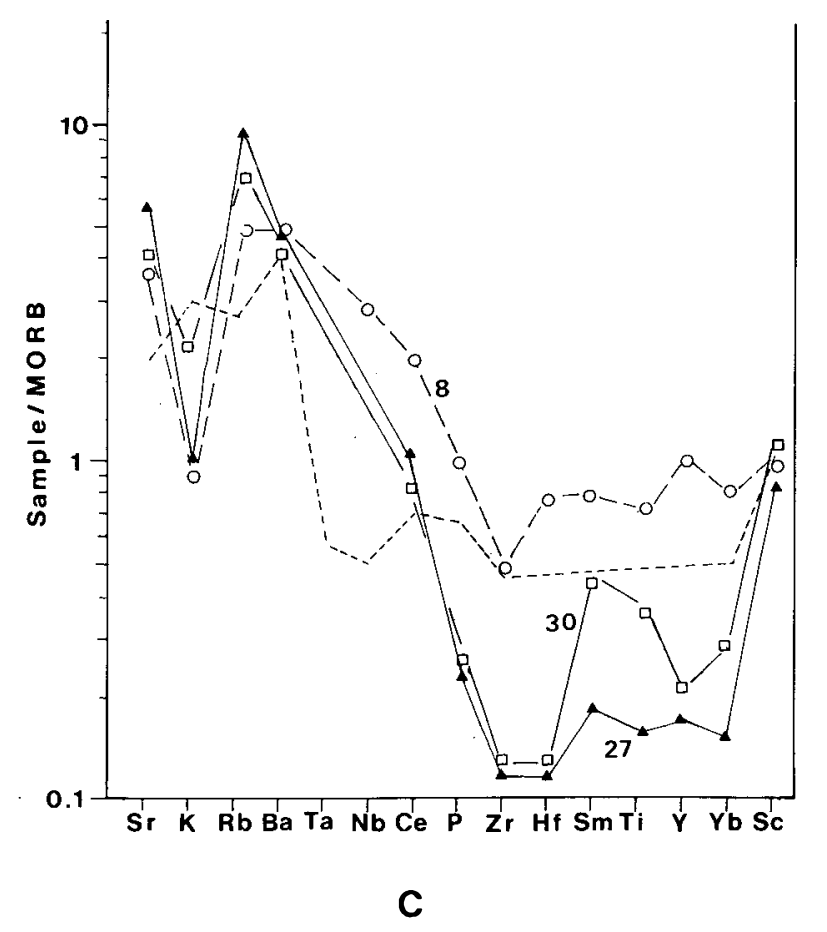

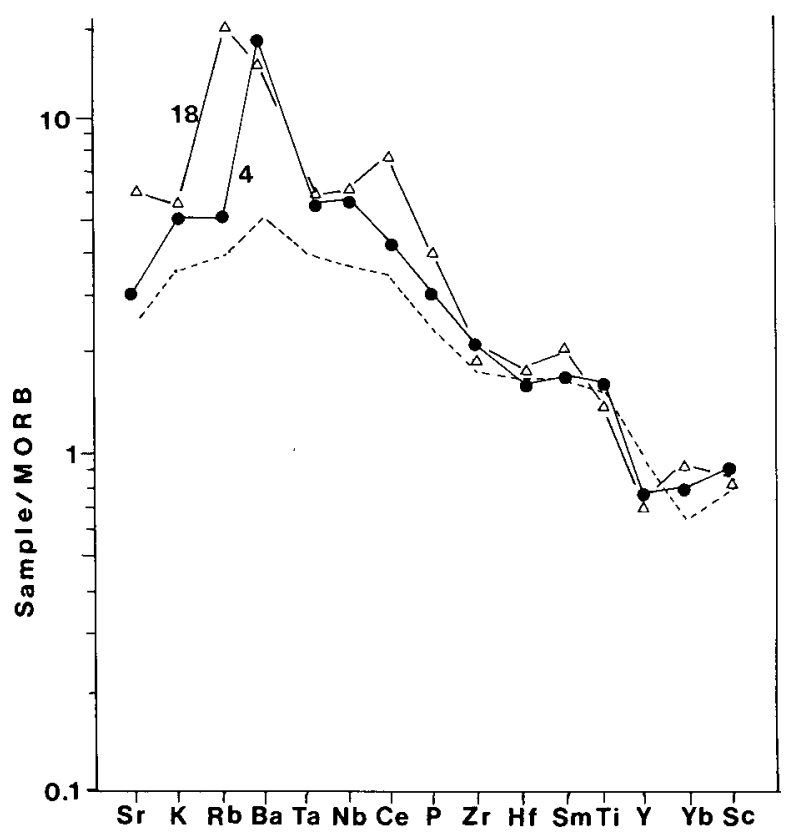

B

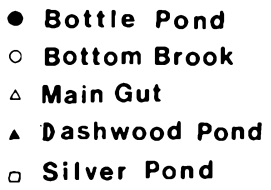

- Bottle Pond

- Dashwood Pond

Silver Pond

Fig. 5. Representative normalised trace element plots for mafic plutons of the Central Gneiss Terrane (symbols as in Fig. 2). (A) Rare earth elements normalised to chondrite abundances (Masuda et al., 1973). Analysis number from Table 1 given for each plot. Shaded field shows range for the nearby ophiolitic Annieopsquotch complex (Dunning, 1987). (B) Spidergram of trace element data for Main Gut and Bottom Brook normalised to MORB abundances (Pearce et al., 1981). Data for average within plate tholeiite (dashed line) after Pearce (1982, Table 1). (C) Spidergram of trace element data for Dashwood Pond and Silver Pond normalised to MORB abundances (Pearce et al., 1981). Data for average volcanic arc tholeiite (dashed line) after Pearce (1982, Table 1).

rocks together with layered mafic plutons indicates rapid stabilisation, uplift and erosion of the crust in late Ordovician to early Silurian time.

The mafic bodies discussed here clearly post-dated Ordovician arc volcanism in central Newfoundland (Williams, 1979), but mantle sources appropriate for production of arc-type plutons may have persisted long after cessation of volcanism. Johnson (1987) has pointed out that in western Melanesia many volcanoes have compositions which do not conform with their present tectonic settings in terms of the conventional models of arc- 
trench systems. He suggests that this is partly due to mantle source regions produced during former subduction. Therefore the generally arc-type rocks of Dashwood Pond and Silver Pond complexes do not necessarily indicate contemporaneous subduction. They differ from mafic rocks of well-documented arcrelated plutonic suites such as Captains Bay (Perfit et al., 1980) and Uasilau-Yau Yau (Whalen, 1985) in several respects. MgO, $\mathrm{Ni}, \mathrm{Cr}$ and $\mathrm{Nb}$ contents are notably high in the Newfoundland rocks relative to the comparison suites, whereas total $\mathrm{Fe}, \mathrm{V}$ and $\mathrm{Zr}$ are low. These characteristics suggest derivation from refractory, depleted sources. Considered as an arc-related suite, the most notable peculiarity of the Dashwood Pond and Silver Pond bodies is the lack of felsic members. The Central Gneiss Terrane exposes deeper crustal levels than contiguous terranes, as shown by the presence of granulite facies metamorphism. Felsic, lowdensity, arc-related magmatic rocks could tend to rise to high levels. Their absence from the Central Gneiss Terrane may be due to deep erosion.

Undeformed mafic bodies of the Central Gneiss Terrane exhibit both within-plate and arc-related characteristics within a single body, or in different bodies of an apparently related suite. Variation between bodies could reflect differences in mantle protoliths due to the presence of relicts from previous events, as discussed above. Variation within a single body may be due to contamination and/or fractionation during ascent and emplacement. Dunning and Chorlton (1985) found evidence of significant crustal contamination in plutons of the Central Gneiss Terrane, and Fox and van Berkel (1988) deduced that circulation of hydrous fluids altered the composition of ultramafic rocks. Whalen and Currie (1984) found magma mixing to be a major process in the Topsails Terrane to the north. Some combination of these factors may be responsible for the unusual variation noted in this study.

\section{ACKNOWLEDGEMENTS}

We are indebted to John Hill and Brendan Murphy for careful critical reviews which have substantially improved the paper. The final versions of the figures were prepared at the Bureau of Mineral Resources, Canberra, Australia. We are also most grateful to the friends on whom we have imposed various versions of this paper. Much of the merit of the final product is due to their suggestions and criticisms, while the defects remain our own.

BEDARD, J.H. 1987. Pre-Acadian magmatic suites of the southeastern Gaspé Peninsula. Geological Society of America Bulletin, 97, pp. 1177-1191.

CAREW, W. 1979. A layered appinitic intrusion in southwest Newfoundland: a field petrographical and geochemical investigation. Unpublished B.S. thesis, Memorial University of Newfoundland, St. John's, Newfoundland.

CHANDLER, F.W. and DUNNING, G.R. 1983. Fourfold significance of an early Silurian U-Pb zircon age from rhyolite in redbeds, southwest Newfoundland. Geological Survey of Canada, Paper 83-1B, pp. 419-421.

CURRIE, K.L. 1987. A preliminary account of the gcology of the Harry's River map-area, southem Long Range of Newfoundland.
Geological Survey of Canada, Paper 87-1A. pp. 653-662.

CURRIE, K.L. and PIASECKI, M.A.J. In press. A kinematic model for southwestern Newfoundland based upon Silurian sinistral shearing. Geology (Boulder).

DUNNING, G.R. 1987. Geology of the Annieopsquotch ophiolite complex, southwest Newfoundland. Canadian Joumal of Earth Sciences, 24, pp. 1162-1174.

DUNNING, G.R. and CHORLTON, L.B. 1985. The Annieopsquotch ophiolite belt of southwest Newfoundland: geology and tectonic significance. Geological Society of America Bulletin, 96, pp. 1466 $-1476$.

DUNNING, G.R., KROGH, T.E., O'BRIEN, S.J., COLMAN-SADD, S.P., and O'NEILL, P. 1988. Geochronologic framework of the central mobile belt in southern Newfoundland and the importance of Silurian orogeny. Geological Association of Canada, Program with Abstracts, 13, p. A34.

FOX, D. and VAN BERKEL, J.T. 1988. Mafic-ultramafic occurrences in metasedimentary rocks of southwestem Newfoundland. Geological Survey of Canada, Paper 88-1B, pp. 41-48.

IRVINE, T.N. and BARAGAR, W.R.A. 1971. A guide to chemical classification of the common volcanic rocks. Canadian Joumal of Earth Sciences, 8, pp. 523-548.

JOHNSON, R.W. 1987. Delayed partial melting of subductionmodified magma sources in westem Melanesia: new results from the late Cainzoic. Pacific Rim Congress 87,pp. 211-214, published by The Australasian Institute of Mining and Metallorgy, Melbourne.

MASUDA, A., NAKAMURA, N., and TANAKA, T. 1973. Fine structures of mutually normalized rare-earth patterns of chondrites. Geochimica et Cosmochimica Acta, 37, pp. 239-248.

MIYASHIRO, A. and SHIDO, F. 1975. Tholeiitic and calc-alkalic series in relation to the behaviours of titanium, vanadium, chromium and nickel. American Journal of Science, 275, pp. 265-277.

PEARCE, J.A. 1975. Basalt geochemistry used to investigate past tectonic environments on Cyprus. Tectonophysics, 25, pp.41-67.

- 1982. Trace element characteristics of lavas from destructive boundaries. In Andesites, orogenic andesites and related rocks. John Wiley and Sons, pp. 525-548.

PEARCE, J.A. and CANN, J.R. 1973. Tectonic setting of basic volcanic rocks determined using trace element analyses. Earth and Planetary Science Letters, 19, pp. 290-300.

PEARCE, J.A., ALBASTER, T., SHELTON, A.W., and SEARLE, M.P. 1981. The Oman ophiolite as a Cretaceous arc-basin complex: evidence and implications. Philosopical Transactions of the Royal Society, A300, pp. 299-317.

PEARCE, T.H. 1968. A contribution to the theory of variation diagrams. Contributions to Mineralogy and Petrology, 19, pp. 142 157.

PEARCE, T.H., GORMAN, R.E., and BIRKETT, T.C. 1975. The $\mathrm{TiO}_{2}-\mathrm{K}_{2} \mathrm{O}-\mathrm{P}_{2} \mathrm{O}_{5}$ diagram; a method of discriminating between oceanic and non-oceanic basalts. Earth and Planetary Science Letters, 24, pp. 419-426.

. 1977. The relationship between major element chemistry and tectonic environment of basic and intermediate volcanic rocks. Earth and Planetary Science Letters, 36, pp. 121-133.

PERFIT, M.R., BRUECKNER, H., LAWRENCE, J.R., and KAY, R.W. 1980. Trace element and isotopic variations in a zoned pluton and associated volcanic rocks, Unalaska Island, Alaska: a model for fractionation in the Alcutian calcalkaline suite. Contributions to Mineralogy and Pctrology, 73, pp. 69-87.

RUSSELL, J.K. 1986. A Fortran 77 computer program for the leastsquares analysis of chemical data in Pearce variation diagrams. 
Computers and Geosciences, 12, pp. 327-338.

SHERVAIS, J.W. 1982. Ti-V plots and the petrogenesis of modern and ophiolitic lavas. Earth and Planetary Science Letters, 59, pp. 101 118.

STEVENS, R.D., DELABIO, R.N., and LACHANCE, G.R. 1982. Age determinations and geological studies. K-Ar isotopic ages Report 16. Geological Survey of Canada, Paper 82-2.

VAN BERKEL, J.T. and CURRIE, K.L. 1988. Geology of the Puddle Pond (12A/5) and Little Grand Lake (12A/12) map areas, southwestern Newfoundland. Newfoundland Department of Mines, Mineral Development Division, Report 88-1, pp. 99-107.

VAN BERKEL, J.T., JOHNSON, H.P., and CURRIE, K.L. 1986. A preliminary report on the geology of the southem Long Range, southwest Newfoundland. Geological Survey of Canada, Paper 86-1B, pp. 157-170.

WHALEN, J.B. 1985. Geochemistry of an island-arc plutonic suite: the Uasilau-Yau Yau intrusive complex, New Britain, P.N.G. Journal of Petrology, 26, pp. 603-632.

WHALEN, J.B. and CURRIE, K.L. 1983. The Topsails igneous terrane of western Newfoundland. Geological Survey of Canada, Paper 83-1A, pp. $15-23$.
1984. The Topsails igneous terrane, westem Newfoundland; - evidence for magma mixing. Contributions to Mincralogy and Petrology, 87, pp. 139-150.

WHALEN, J.B., CURRIE, K.L. and VAN BREEMEN, O. 1987. Episodic Ordovician-Silurian magmatism in the Topsails Igneous terrane, western Newfoundland. Transactions of the Royal Socicty of Edinburgh, 78, pp. 17-28.

WILLIAMS, H. 1979. Appalachian orogen in Canada. Canadian Journal of Earth Sciences, 16, pp. 792-807.

WILLIAMS, H. and CAWOOD, P.A. 1985. Relationships along the eastem margin of the Humber Arm allochthon between Georges Lake and Comer Brook, western Newfoundland. Geological Survey of Canada, Paper 86-1A, pp. 759-765.

WILLIAMS, H. and STEVENS, R.K. 1974. The ancient continental margin of eastem North America. In The geology of continental margins. Edited by C.A. Burk and C.L. Drake. Springer-Verlag, New York, pp. 781-96.

WILLIAMS, H., COLMAN-SADD, S.P., and SWINDEN, H.S. 1988. Tectonic-stratigraphic subdivisions of central Newfoundland. Geological Survey of Canada, Paper 88-1 A, pp. 91-98. 